\title{
DOCUMENTAL STUDIO AND 3D RECREATION OF THE SAN ILDEFONSO'S SCHOOL FACADE, ALCALA DE HENARES.
}

\author{
E. Echeverría ${ }^{\text {* }}$, E. Castaño ${ }^{\text {a }}$ F . Casa ${ }^{\text {a }}$, F. Celis ${ }^{\text {a }}$ P. Chias ${ }^{\text {a }}$ \\ ${ }^{a}$ Dept. of Architecture, School of Architecture, 28801 Alcalá de Henares, Spain - (ernesto.echeverria, enrique.castano, fernando \\ .casa, flavio.celis, pilar.chias)@uah.es
}

\section{Commission II}

KEY WORDS: Laser Scanning, Georeferencing, $16^{\text {th }}$ Century Architecture, Spain, University of Alcala.

\begin{abstract}
:
In order to make the last important restoration of the University of Alcala's facade, an important documentation work and 3D recreation has been done, under three premises: historical documental study, study of the materials and, finally, 3D recreation of the facade. Part of these competences have been assumed by our research group under the safety net of the project that we come to tell in this communication.
\end{abstract}

\section{INTRODUCTION}

\subsection{The site}

Many authors (Echeverría, 2005, 2010, and 2013) have permitted to follow the creation and evolution of University of Alcala, and the San Ildefonso's University College (Colegio Mayor de San Ildefonso) current Rector's office of the University of Alcala, whose main facade (object of this article) is in San Diego's square.

The facade of the San Ildefonso College is the main imagen of the University of Alcala. This monument is visited each year for thousands of tourists.

The name of the square comes from and old convent (Figure 1) situated in the oriental side of this square, which was demolished in 1859 (figure 2) and replaced by the Prince's headquarters, currently Learn and Research Center of the University of Alcala.

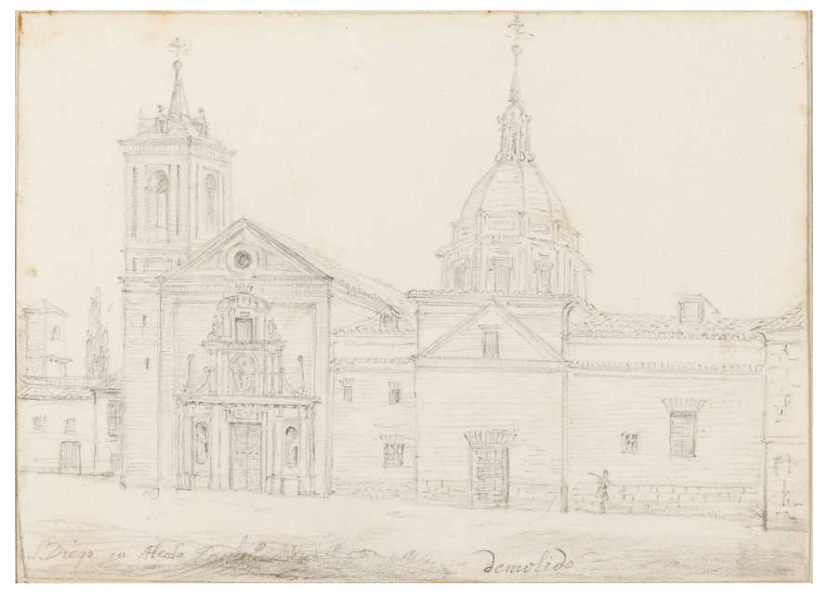

Figure 1: Facade of the demolished convent of San Diego. Valentín Cardera. Between 1820 and 1859.

\subsection{Historical review}

The first stone of the building was placed by the Cardinal Cisneros in Mars 14th 1499 and it was opened to the University use in 1509. Pedro Gumiel was in charge of the construction. This first building was built with humble materials, like clay and wood.

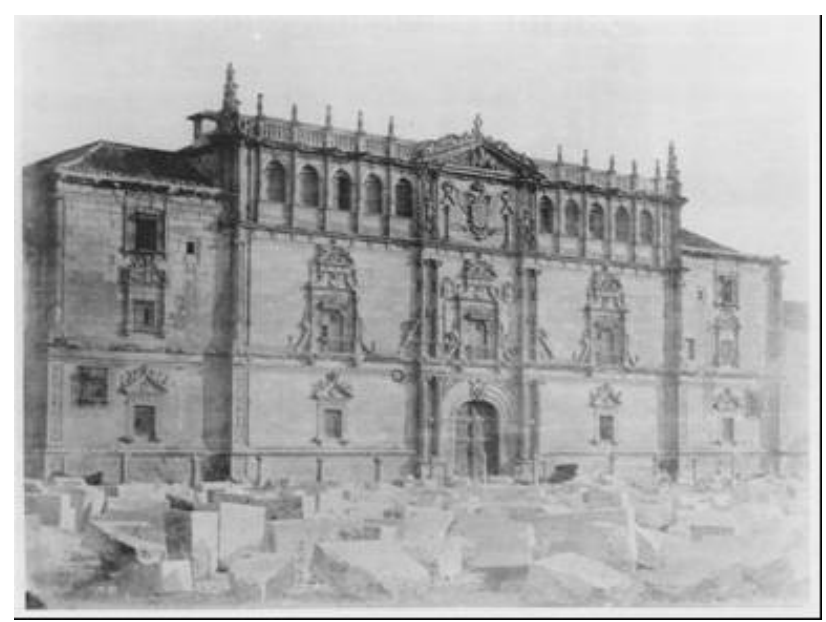

Figure 2: San Diego's square during the demolition of the San Diego's convent in 1859 for the new headquarters construction. Picture by J. Laurent, from the collection of J. F. Huerta.

Afterwards, a new facade is built (over the original made of clay) by Rodrigo Gil de Hontañón between 1537 and 1553. It was always said that the stone came from Tamajón (Guadalajara), but recent researches (García, 2013), place the quarry in the Vellón village (Madrid), in some estates whose previous owner was the Cardinal Cisneros.

The facade consists in one central module with three parts of height of which the upper part is set up by a gallery with

* Corresponding author 
semicircular arches, and two lateral wings, with only two parts with different height as those of the central one. The central module is also form by three vertical modules, being the second one the fanciest.

The building has experienced multiple and varied interventions (Quintana, 2014) all over its long history due to the wear of the passing of time and its change of use. As an example, we have the tender proposed to restore the whole building due to the poor conservation status in which finally the architect Ventura Rodriguez (Figure 4) took charge to build a new chapel in the market square's place, but it was never built.

Regarding to the facade, the most important intervention was made by Anibal Alvarez between 1916 and 1927. Many sculptural and ornamental ensembles were completed and almost the $40 \%$ of the plinth of granite was substituted because of its damage of the capillarity.

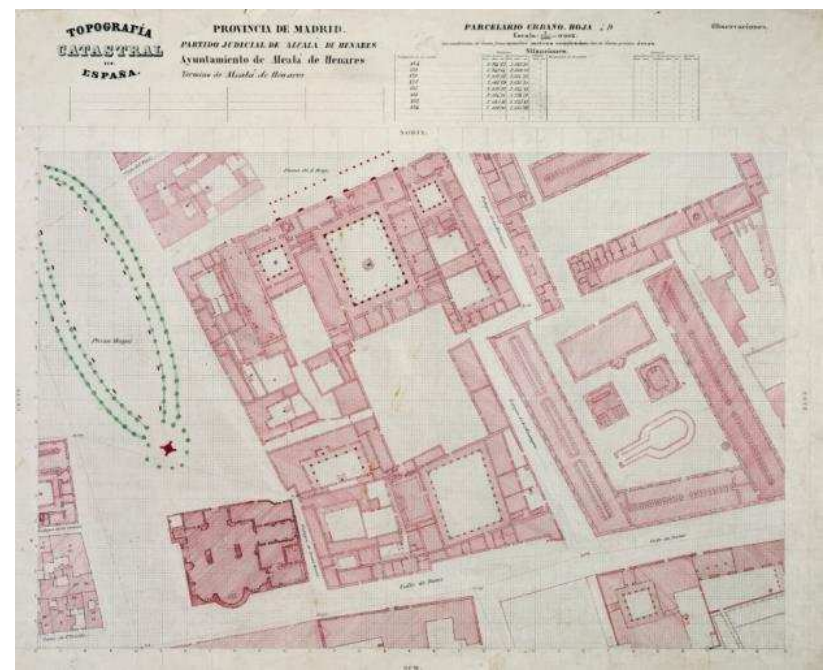

Figure 3: Kilometric sheets. 1/500 from Servicio Geográfico Nacional. 1870. Sheets D4.

\subsection{Graphic database}

In the research on heritage, an important studio tool to evaluate the temporal evolution of the Monument is the analysis of graphic documents (Echeverria, 2015), which allows us to add information to other studies. In the case of the University of Alcala, this information is not very abundant and has a testimonial nature given the low precision of it.

Antoine Babuty Desgodetz (Celis, 2006) began the technique of the correct lifting of ancient monuments and the enhancement of these buildings from the appearance of the publication in 1682 "les edifices antiques de Rome, dessinés et messurés tres exactament".

The first document, concerning the construction of the College of San Ildefonso, dates from 1511 (figure 5) describes in plant of the block where the current rectorate of the University of Alcala is located. It can be seen that there is no square, there was a street ahead.

The following image is an anonymous picture (figure 6), from the middle of the seventeenth century. It is about the Cardinal Cisneros riding a horse, between the University of Alcala facade and the Oran Castle (Rivera, 2016).
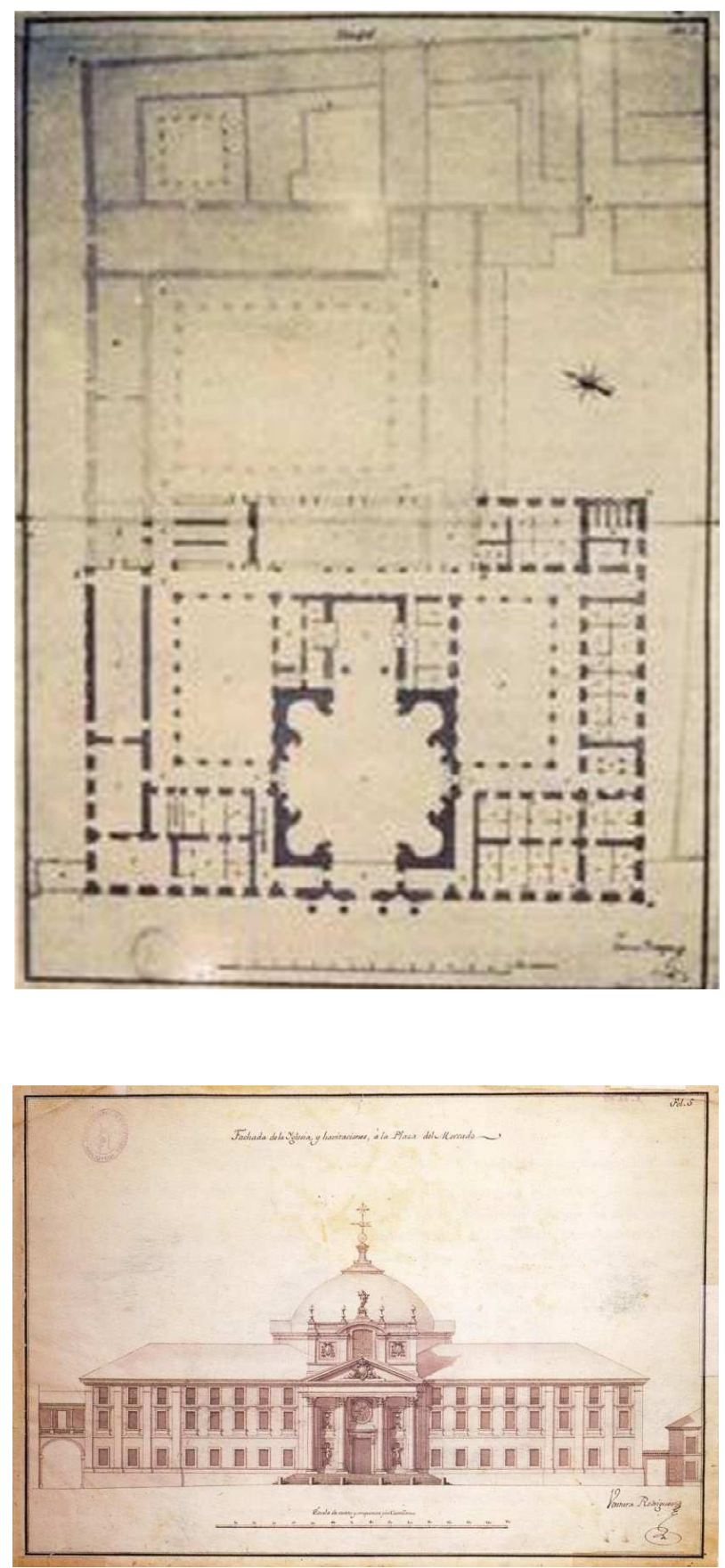

Figure 4: Principal floor plan and main facade of the San Ildefonso's residence hall and temple, from Ventura Rodriguez, year 1764 (Funds of the Superior Technical School of Architecture of Madrid)

One of the first pictures (figure 2) of the facade is from 1859, where it can be appreciated all over the square the dispersed demolition material of the San Diego's convent, which had the previous mentioned facade to the square.

We have other drawings, like the engraving of Valentín Carderera from 1846, where one can appreciate the west end of the facade, close to the San Ildefonso's chapel (figure 7). 


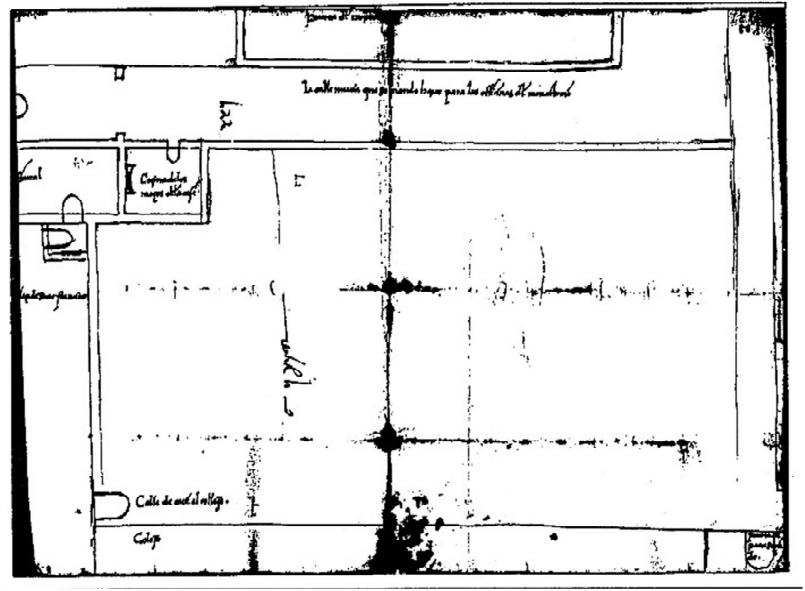

Figure 5: Sketch of Pedro de Gumiel. 1511 (AHN)

In the 19th century, the first cartographic planes appeared with some precision. The first was that of Pedro Ortiz de Pinedo, dated at Alcalá on July 20, 1837 (Archivo General Militar de Madrid, symbol SH-M-I / 12). Subsequently, we have the kilometers sheets (hojas kilometricas) of the National Geographic Service of the Ministry of Finance of 1870 (figure 3).

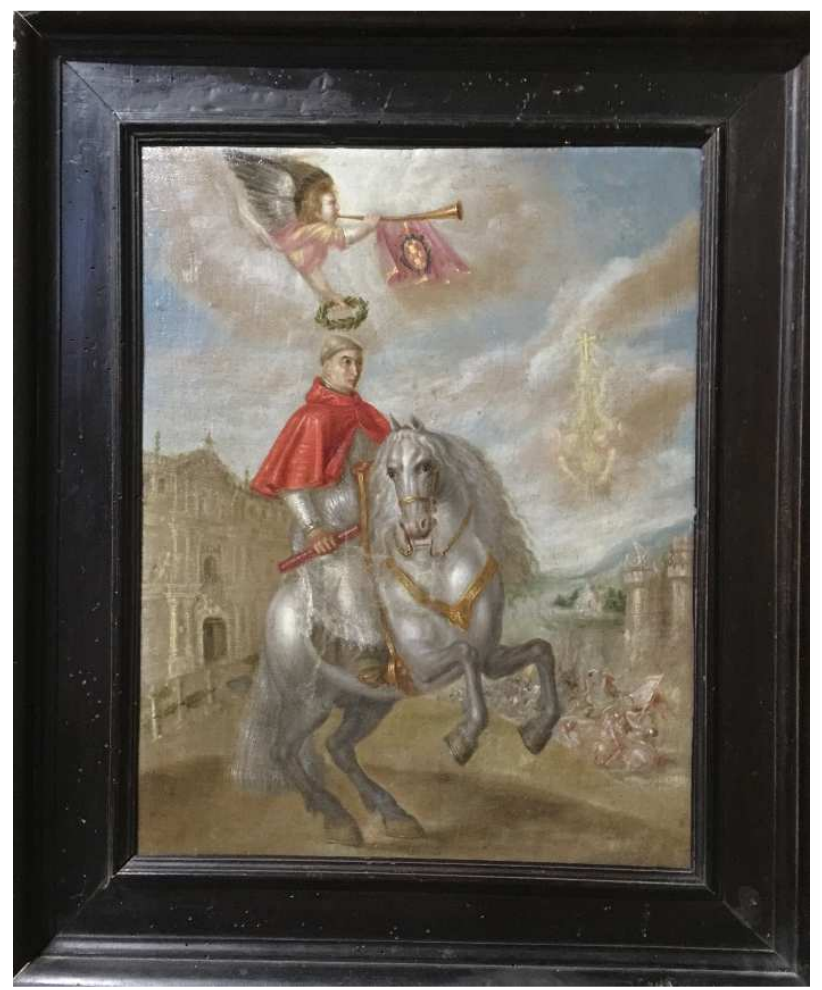

Figure 6: The Cardinal Cisneros riding a horse, between the University of Alcala facade and the Oran Castle. Parish Church, Cardeñosa, Avila. (Rivera, 2016, 27)

\section{METHODOLOGY}

In this article, we will proceed to explain all the process followed in the research. The facade is, in this moment, being in the process of rebuilding, so the results will be modified in real time. As Porcuna indicates $(2016,279)$.

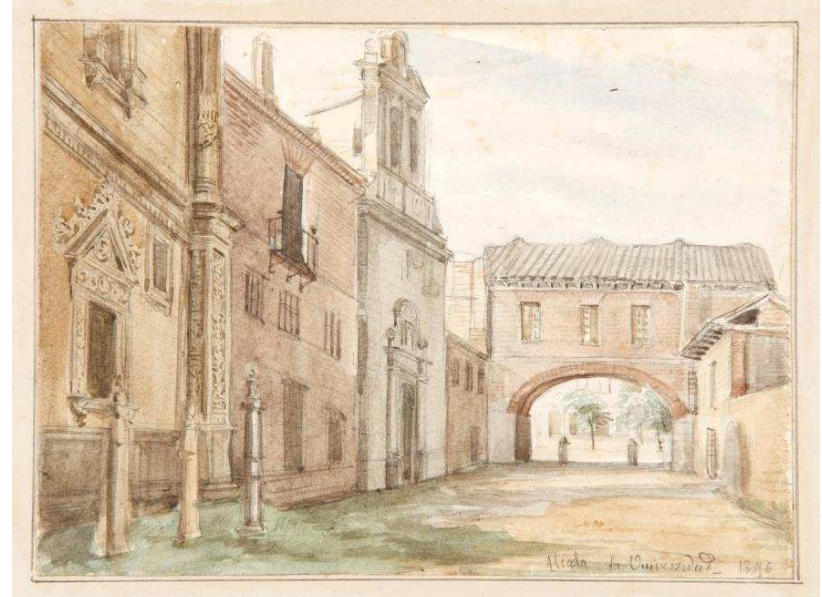

Figure 7: Partial view of the San Ildefonso's residence hall. Engraving 1846. Carderera.

The digital modelling in 3D constitutes one of the more powerful tools in the documentation, researching, divulgation and put in value of the cultural patrimony.

The appearance of 3D scanners for the measurement of threedimensional real objects has long revolutionized data collection systems (Navarro, 2007). During this time several generations of 3D scanners have been increasingly effective, accurate and of smaller size and weight. In spite of this, architects continue to use traditional techniques as the basis of work, but taking advantage of the speed and precision of the new techniques (Mesa, 2007 and 2009) (Goitia, 2010).

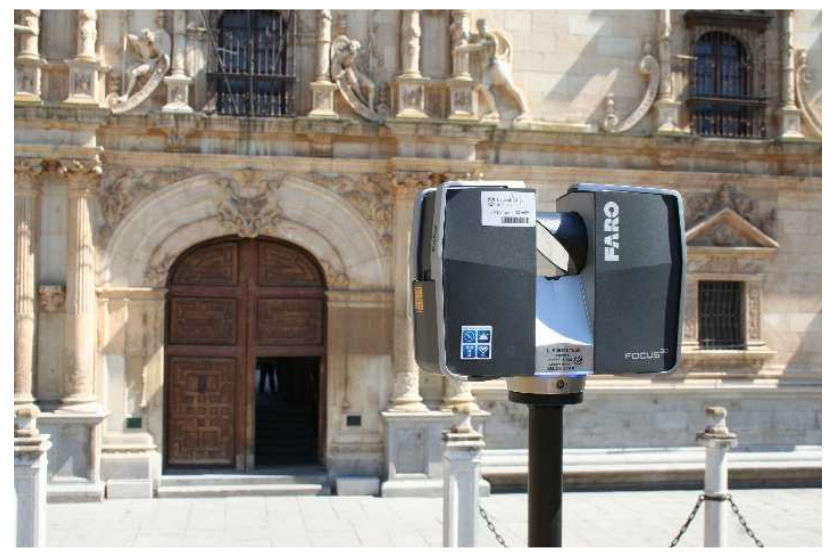

Figure 8: Picture of the laser scanner FARO FOCUS 120 and the San Ildefonso College Facade.

The principal 3D recreation was done during the summer of 2016 and now a scaffold is built covering the whole facade. This scaffold permits to review and specify all the data. The finalization of the work is expected to the summer 2017 so that, new data will be impossible to add before the congress take place. As a proof of the communication development the equipment used for the data collection is: a laser FARO Focus 3D and the SCENE program (FARO's contribution).

For the photogrammetric studio we have used Agisoft Photoscan, and the pictures have been taken by a camera Canon 6000 . 
During the work, using the scaffold, we pretend to proceed in the detailed documentation of different sculptures mixing the photogrammetric and optic scan techniques (Molero, 2016).

First of all, a qualitative studio was done beginning from the perception and designs of the research group. It allowed to establish a guideline to set up the positioning places. After this first step, we considered to lift the acquisition points of the image in order to collect the data in perpendicular to the facade in the highest points. To do it, a lifting platform was used (figure 9).

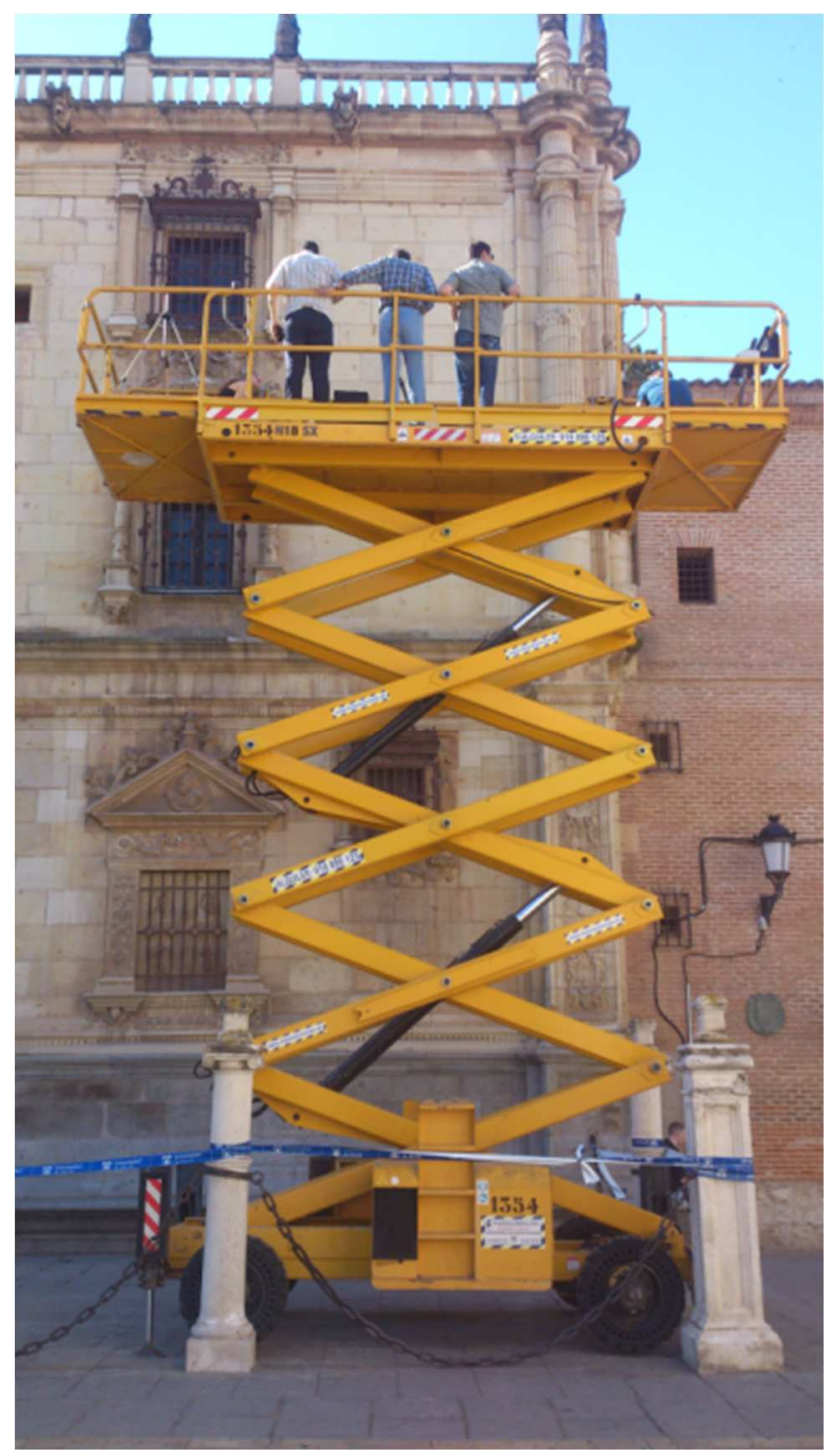

Figure 9: Location of the platform in one of the scan and photographed position.

Using the lifting platform, it has been possible to divide the surface of the facade into a $5 \times 5$ grid in order to avoid blind areas to the laser beam of the scanner due to the large amount of relief on the façade (figure 10). Subsequently 2 new measurements were made from both ends at street level to complete some detected blind zone.

The presence of tourists near the façade at all hours was one of the main difficulties, being necessary to close the pedestrian crossing area temporarily. A particularly complicated position to execute was the main door, which must be done outside the opening hours of the building, due to the interference of visitors to the building. Thanks to the platform it could be possible to take pictures for the photogrammetry and the scan lectures with the proceeding parameters.

\begin{tabular}{|l|l|}
\hline LASER SCAN PARAMETER & FARO FOCUS 3D \\
\hline CHOSEN OUTLINE & Outside from 20m \\
\hline $\begin{array}{l}\text { RESOLUTION AND } \\
\text { QUALITY }\end{array}$ & $\begin{array}{l}\text { Resolution: } 1 / 6 \\
\text { Quality: } 4 \mathrm{x}\end{array}$ \\
\hline SCAN RANGE & $\begin{array}{l}\text { Vertical range: from -60 } \\
\text { to } 90^{\circ} \\
\text { Horizontal range: from } \\
90^{\circ} \text { to } 270^{\circ}\end{array}$ \\
\hline SENSORS & $\begin{array}{l}\text { Use clinometer: activated } \\
\text { Use compass: activated } \\
\text { Use altimeter: activated }\end{array}$ \\
\hline COLOR PARAMETERS & $\begin{array}{l}\text { Weighted measuring to } \\
\text { the center }\end{array}$ \\
\hline $\begin{array}{l}\text { ADVANCED } \\
\text { CONFIGURATION }\end{array}$ & $\begin{array}{l}\text { Clear contour: activated } \\
\text { Clear sky: activated }\end{array}$ \\
\hline
\end{tabular}

Table 1. Laser scan parameter

Different positions were proposed for each part of the outside of the facade. Positions with the most seen surface of the building were searched, so that, the vertical scan range was always the maximum, from $-60^{\circ}$ to $90^{\circ}$, but the horizontal range was reduced, from $90^{\circ}$ to $270^{\circ}$, due to the fact that the new angle didn't need to be as much larger as the first one because it was only one plan.
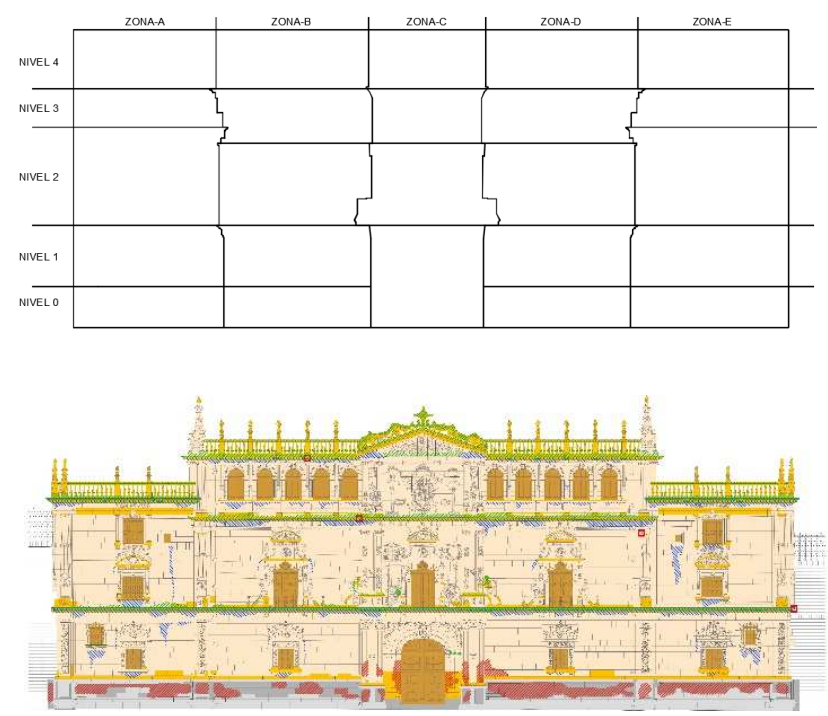

$+$

Figure 10: Location of scanner position and view of facade plan.

With these position combinations the record of almost all the space of the facade's outside was possible with around 50 million of points with coordinate $\mathrm{X}-\mathrm{Y}-\mathrm{Z}$, including the detailed photographic record in each position. After this step, the different 
scans were put together to reach the complete point cloud of the building's facade.

\section{PROSPECTIVE}

From this initial work carried out with the known image of the University, it is intended to continue with a modeling of the public spaces of the rest of the College of San Ildefonso in order to participate in models of augmented reality.

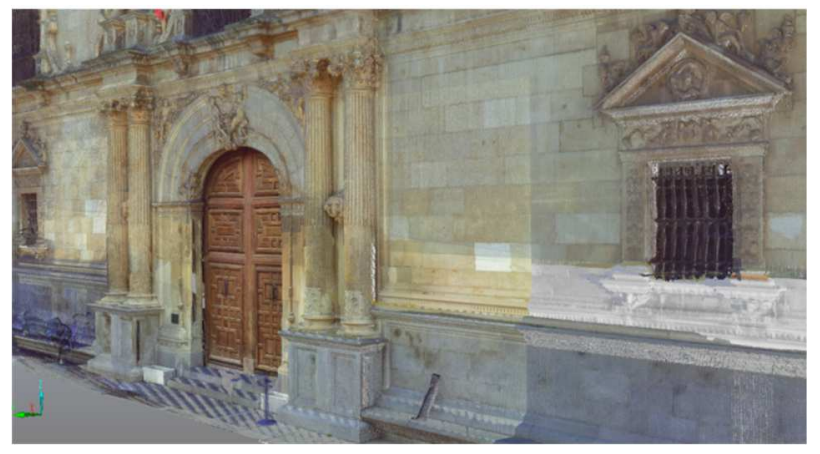

Figure 11: Model detail of the entrance zone during the work

On the other hand, it is intended to put the data obtained within the INSPIRE standards. They are two main data specifications inside INSPIRE where cultural heritage data are site: Data Specification on Protected Sities, and the Data Specification on Area management / restriction / regulation zones and reporting units (Chias and Abad, 2015).

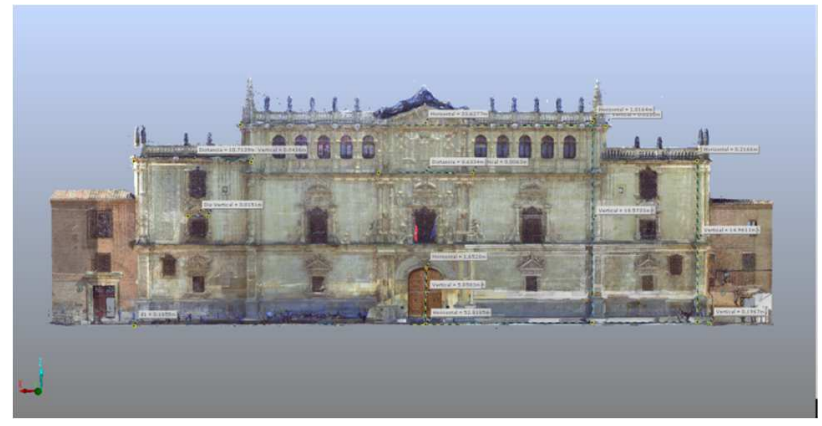

Figure 12: Work process image (orthophoto model)

\section{CONCLUSIONS}

As we have seen, the facade of the College of San Ildefonso is the most well-known image of the University of Alcala. There are several historical images of this facade, but for the first time has been obtained a representation almost real of its current state, not only flat, but in 3D to be used by researches, conservators, and communicators. From the $3 \mathrm{D}$ model you can get plans, sections, orthophotos, or partial details.

From the data obtained, a 3D recreation has been done and is now being using as a base for the restauration work and it will be used to compare it with the final result. A new data base will be created with the new technologies (photogrammetry, CAD, digital photography, laser scan) in order to facilitate the approach and better knowledge of our patrimony. This facade's data map (HGIS) will be the building's DNA with the record of all the significant variables: form, history, materials, color, conservation and maintenance during the monument's life. Thanks to this map, a new project of augmented reality can be developed in order to visualize the University's buildings in an interactive way.

\section{ACKNOWLEDGEMENTS}

The authors would like to thank Universidad de Alcala, and the OGIM (Maintenance and Infrastructures Management Office Oficina de Gestion de Infrastructuras y Mantenimiento) for their help and support along this research project. We also acknowledge Alvaro Mozas, Jose Luis Vigara, Ines Mendoza and Lourdes Nadal who collaborated in the field work.

\section{REFERENCES}

Alitany, A., Redondo, E. and Adas, A., 2014. Una nueva metodología para la documentación y modelado 3D de elementos de patrimonio arquitectónico. Un estudio de viabilidad y de caso. Los miradores colgantes de madera "Roshan" en la ciudad histórica de Jeddah. Revista EGA Expresión Gráfica Arquitectónica n²4, Valencia, p.176.

Almagro, A. and Soler E., 2014. Levantamiento de bóvedas de arcos entrecruzados: Técnicas aplicadas al caso de la torre del homenaje del castillo de Villena (Alicante). Revista EGA Expresión Gráfica Arquitectónica nº 23, Valencia, p. 204.

Buill, F., Núñez, Ma . A. and Regot, J., 2013. Técnicas de captura masiva de datos para el levantamiento y modelado de monumentos medievales. Revista EGA Expresión Gráfica Arquitectónica ${ }^{\circ} 21$, Valencia, p.62

Celis, F., 2006. Desgodetz y los orígenes del levantamiento moderno. Revista EGA Expresión Gráfica Arquitectónica n 11 , Valencia, p.76.

Chías, P. and Abad, T., 2015. Spatial Data Infrastructures and Spanish Cultural Heritage: the INSPIRE Framework applied to the Monastery of El Escorial. Journal of Map \& Geography Libraries, 11(2), pp. 245-265.

Echeverría, E., 2005. El campus universitario de Alcalá de Henares. Análisis y evolución. Tesis doctoral. UPM. Madrid.

Echeverría, E., 2010. La fundación cisneriana como catalizador del urbanismo de Alcalá hasta su traslado en 1836. Universidad de Alcalá: de las armas a las letras. Alcalá de Henares: Universidad de Alcalá, p.15-35.

Echeverría, E., Casa, F., Celis, F., and Chias, P., 2013. The University of Alcala de Henares (Madrid, Spain), as a dynamic example and laboratory of the recovery, rehabilitation, and conservation of the cultural heritage. ISPRS Archives Volume XL-5/W2. 2-6 September. p. 237-243.

Echeverría, E., Celis, F., and Casa, F. da, 2015. Drawing as a research tool: reconstruction of the trip time of the urban image of Alcala de Henares. Revista EGA Expresión Gráfica Arquitectónica $n^{\circ}$ 25, Valencia, p. 180.

Fernández, J. A., 2002, Criterios y métodos para la modelación digital del Patrimonio Arquitectónico. Revista EGA Expresión Gráfica Arquitectónica n 7, Valencia, p. 73.

Fantini, F., 2012. Modelos con nivel de detalle variable realizados mediante un levantamiento digital aplicados a la arqueología. Revista EGA Expresión Gráfica Arquitectónica $\mathrm{n}^{\circ}$ 19, Valencia, p. 306. 
García de Miguel, J.M.; 2013. Estudio petrológico de la fachada principal del colegio Mayor de San Ildefonso y de las del Patio de Santo Tomas de Villanueva. Restauración contemporánea. Ciudades universitarias, ciudades Patrimonio de la Humanidad. La manzana fundacional Cisneriana de la Universidad de Alcalá. Ed. Universidad de Alcalá, Alcalá de Henares. Pag.527 a 550 .

Goitia, A.; 2010, Restituir, Redibujar, Aventurar. Estrategias para documentar tres puertas monumentales de Madrid. Revista EGA Expresión Gráfica Arquitectónica nº15, Valencia, p.74.

Mataix, J., León, C., and Montes Tubio, F. de P., 2013. Fortalezas y debilidades de la técnica de Levantamiento gráfico con escáner laser para la catalogación del Patrimonio Cultural. Aplicación a la iglesia de San Francisco de Córdoba. Revista EGA Expresión Gráfica Arquitectónica nº 21, Valencia p.216.

Mesa, A. de, Regot, J., Núñez, Mª. A. and Buill, F., 2007. Estrategias de modelado en la Sagrada Familia. Revista EGA Expresión Gráfica Arquitectónica nº 12, Valencia p. 92.

Mesa, A. de, Regot, J., Núñez, Mª A., and Buill Pozuelo, F., 2009. Métodos y procesos para el levantamiento de reconstrucción tridimensional gráfica de elementos del Patrimonio cultural. La iglesia de Sant Sever de Barcelona. Revista EGA Expresión Gráfica Arquitectónica n ${ }^{\circ}$, Valencia. P. 82.

Molero, B., Barba, S., and Álvaro, A., 2016. Documentación del Patrimonio Cultural. Método basado en la fusión de técnicas fotogramétricas y de escaneado óptico de triangulación. Revista EGA Expresión Gráfica Arquitectónica nº 28, Valencia, p.236.

Navarro, P., Erraez, J. and Navarro, I., 2007. La geometría interna de un escáner laser. Funcionamiento de sus espejos. Revista EGA Expresión Gráfica Arquitectónica nº 12, Valencia, p.102.

Pernas, M.I., 2012, Escalera de honor de Santo Estevo de Ribas de Sil. Alzados geométricos. Revista EGA Expresión Gráfica Arquitectónica nº19, Valencia, p.158.

Piquer, J.C., 2008. Análisis y reconstrucción virtual del Palacio de Valencia, (1239-1810). Desde la planta de Vicente Gascó de 1761 a los planos de Manuel Cavallero de 1802, resultados de la investigación gráfica. Revista EGA Expresión Gráfica Arquitectónica $\mathrm{n}^{\circ} 13$, Valencia, p. 212.

Piquer, J.C., Capilla-Tamborero, E., and Molina-Siles, P., 2015. La reconstrucción del patrimonio y su aplicación metodológica. Revista EGA Expresión Gráfica Arquitectónica n²5, Valencia, p.258.

Porcuna, D., Córdoba, R., Sanz Cabrera, R., and Montes Tubio, F. de P., 2016. Metodología para la reconstrucción virtual interactiva en modo videojuego del Patrimonio cultural. Aplicación al castillo medieval de Torreparedones (Baena). Revista EGA Expresión Gráfica Arquitectónica n²8, Valencia, p. 278.

Quintana, J.L., 2014, Colegio Mayor de San Ildefonso. Rectorado. Universidad de Alcalá. Patrimonio de la humanidad - World Heritage. Ed. Universidad de Alcalá, Alcalá de Henares. Pag. 38 y 39.
Rivera, J., 2016. Arquitectura Universitaria. Ciudades Patrimonio Mundial. II Simposio Internacional de Arquitectura Universitaria. Servicio de Publicaciones Universidad de Alcalá.

San José, J., 2011. La réplica en el contexto de la gestión del patrimonio inmueble. Tres capillas Sisxtinas. Revista EGA Expresión Gráfica Arquitectónica nº 17, Valencia p.113 